\title{
Idiosyncratic Risk and Asset Pricing
}

\author{
Marselinus Asri* \\ e-mail: marselinus.asri@yahoo.co.id \\ *Accounting Department, Atma Jaya Makassar University-Indonesia
}

\begin{abstract}
The purpose of research is to investigate the accrual principles in Accounting that contained in the Company's Financial Statements. The accrual principle is reflected in the Balance Sheet and Income Statement. Accrual measurements in the Balance Sheet are measured using PersistenceCurrent Operating Accrual, Persistence Non-Current Operating Accrual. Idiosyncratic risk reflects the specific information about the company and it will fluctuate according to the information itself.

To measure the idiosyncratic risk in this study five factors of Fama-French Model were used (Fama and French 2014). Asset Pricing Measurement uses the Dividend Discount Model to predict stock prices.

The samples used in this study are listed below. The Manufacturing Company is selected with consideration for accrual measurement of accounts receivable, inventory, investment, and liabilities. The sample was chosen by purposive random sampling method. The number of samples generated by this method is 145 companies with full reports for 2010-2015.

Using the SEM AMOS Ver.24 and Sobel Test-Path Analysis, the results show that Current Operating Accrual has a negative and significant relationship to the idiosyncratic risk and stock price. For non-current Operating Accrual, variables have a positive and significant relation. By using Sobel Test, the test result shows that idiosyncratic risk has mediation effect in Persistence Current Operating Accrual, NonCurrent Operating Accrual relationship to stock price.
\end{abstract}

Keywords: Persistence Current Operating Accrual, Persistence Non-Current Operating, Idiosyncratic Volatility, Asset Pricing 


\section{A. Introduction}

Traditional CAPM model, the market return measurement refers to the variation of individual stock movements to market return, while variations in specific stock return volatility refer to the idiosyncratic, the residual variance in regression model CAPM. The idiosyncratic volatility increases the researcher's attention when the investor cannot fully diversify due to budget constraints and the ability to diversify. In the CAPM, the return of an asset is determined only by the systematic risk. In theory, the $C A P M$ is very useful in explaining and predicting the relationship between risk and expected a return, but the empirical facts show that the model is not able to explain the phenomena (Roll, 1977).

Roll and Subrahmanyam (2010); Roll et al., (2014); Prono (2015) states that the CAPM cannot be held in a variety of conditions or in other words the $C A P M$ is often inappropriately used to predict the value of an asset. Roll (1977) explains that empirical testing provides results that are single stock price index is a proxy that is bad in the CAPM.

The risk is one of the main factors that investors consider when making investments. The risk of securities consists of two components, which are a diversifiable risk and non-diversified risk. Portfolio securities are performed by investors to reduce diversifiable risk, while non-diversified risks will remain attached to each individual securities. Capital's stock price Model (CAPM) developed by Sharpe (1964) and Lintner (1965) have long formed the mindset of academics and practitioners on the relationship between risk and return.

Sloan research results (1996) found a negative correlation between the rate of accrual of subsequent stock return has given rise to numerous studies. Research at the company level is based on the US market. Durnev et al., (2003); Zhu et al. , (2014); Durnev et al., (2016) showed that idiosyncratic risk is positively correlated with stock price informativeness. Accrual Anomaly has a positive and significant impact on the idiosyncratic risk. Investors looked reflect accrual accounting policies and the degree of flexibility of the manager. Managers can use judgment in financial reporting to alter the financial statements in order to achieve certain goals and means increased risk for investors (Asri et al. 2017) 
Indonesian capital market showed a positive effect of idiosyncratic volatility, although not as strong as documented evidence to Malaysia, Singapore, and Thailand (Nartea et al., 2011; Nartea et al., 2013). Based on these considerations, to answer the variation pattern of this relationship researchers used an idiosyncratic risk as mediating variables that explain the relationship with the accrual rate in the stock price perspective prospect theory frame.

The ability of idiosyncratic risk in determining the formation of stock price becomes the focus of this research. Idiosyncratic risk as an indicator forming stock prices in the capital. Based on the above arguments, the formulation of this research are summarized as follows: in the context of Indonesia's capital market, whether there is an anomalous phenomena accrual, whether the formation of anomalous accrual and persistence of accruals affect stock prices and whether investors consider idiosyncratic risk in the decisions that shape stock prices. Kahneman and Tversky (1979) introduced the theory of prospects and developed the theory of prospects to explain why a person makes certain decisions from his psychological side. Prospect theory denies expected utility theory that explains that their individual decisions are rational and linear. Prospect Theory explains the framing effect, certainty effect, insurance effect, and the endowment effect.

Prospect theory states that in making decisions, people tend to focus on the prospects, namely the prospect of gains and losses prospects, rather than on total wealth. As for, which is used as a reference point in calculating profit and loss always change from time to time. Furthermore, the decision-makers perceive a person or prospect (outcomes) in the form of the value function. This is consistent with the main conclusions Kahneman and Tversky (1979) explains that the function of the values defined in terms of gains and losses. Value function explained that in making decisions, people tend to be risk-averse when it is in the domain of profit and risk-seeking when it is at a loss domain. The loss function is represented by a more concave and steep curve, while the function of the profit value is represented in the form of a convex curve and not so steep. Relationships between variables in this study are based on prospect theory, the theory of real options, stock prices and the development of risk models. This study uses idiosyncratic risk as a mediating variable linking persistence current operating accrual, persistence non-current operating, 
on stock prices. To build a model of the relationship between the operating current accrual persistence, persistence operating non-current accrual on the $r$ idiosyncratic risk use of real options theory. Model of the relationship between idiosyncratic risk to the stock price using the prospect theory.

Reflecting idiosyncratic risk specific information about the company and fluctuate according to the information itself (Goyal and Santa-Clara, 2003). Factors that may affect this risk are announcements about seasonal earnings information, supplies and company requests and the dynamics of corporate competition. Company earnings information can be observed from the accrual quality in the financial statements. It is also possible idiosyncratic risk arises because of government regulations that have a direct impact on certain industries.

This study is urgent because of the different characteristics in assessing risk in the CAPM model that is not in accordance with the conditions of the Indonesian capital market. Changes in specific information that often occur affect a particular company or industry to be the main basis of risk assessment by investors. This consideration should be in the idiosyncratic model.

\section{B. RESEARCH METHODS}

The population is all registered companies in IDX in the period 2010-2015 recorded 154 companies. The sample in this study determined using purposive sampling method, the sampling technique with consideration or certain criteria, namely: the Company was sampled company listed on the Stock Exchange in 2010-2015 without delisting.The Company is not late in issuing its audited financial statements as of December 31, 2010-2015.

The type of data used in this study is documentary data in the form of annual financial statements and quarterly companies listed on the Indonesia Stock Exchange (IDX) period 2010-2015. While the source of the data used in this research is secondary data in

\section{Stock Price}

Fama and French (2006) using the dividend discount model and the clean surplus equity accounting defines market value as follows. 


\section{Persistence Current Operating Accrual}

(Richardson et al. 2005) Developed from Sloan Research (1996) by connecting reliability in the measurement of accrual persistence of earnings and stock prices. (Richardson et al. 2005) equation fix Total Accrual used in Sloan (1996) further describes the accrual component.

In this equation, $\triangle C O$ translated into changes in current assets excluding cash and short-term investments $(\triangle C O A)$ minus the change in short-term liabilities excluding short-term debt ( $\triangle C O L)$.

[ $\Delta$ Current Assets- $\Delta$ Cash and Short Term Investments] - [ $\Delta$ Current Liabilities$\triangle$ Debt in Current Liabilities]

\section{Persistence Non-Current Operating Accrual}

The persistence of non-current operating accrual ( $\triangle N C O$ ) is the change in noncurrent assets do not include investment in non-equity long-term and advances $(\triangle N C O A)$ reduced by changes in long-term liabilities, excluding long-term debt $(\triangle N C O L)$.

[ $\Delta$ Total Assets - $\Delta$ Current Assets- $\Delta$ Long Term Investments and Advances] -

[ $\Delta$ Total Liabilities- $\Delta$ Current Liabilities - $\Delta$ Long Term Debt]

Five-factor model of Fama French (Fama \& French 2014b) carried out by regressing excess return using five factors:

$R i t-R F t=a i+b i\left(R_{M t} R_{F t)}+\right.$ the + hi HMLt SMBt RMW +ri + ci CMA + ei

1. the difference between the return of the market portfolio,

2. difference return of portfolio of small stocks to the portfolio return small stock large stock deductible (Small Minus Big - SMB),

3. the difference between the return of the portfolio with a ratio Book To Market (BTM) high-yielding portfolio with lowBTM ratio (High Minus Low$H M L)$

4. RMW difference between returns on portfolio diversification and low profitability

5. CMA difference between returns lower stock portfolio diversification with a high investment company. 


\section{RESEARCH RESULTS}

The descriptive statistical analysis used to determine the description of the study variables: the magnitude of Accrual Operating Current, Current Operating Non-Accrual, Financial Accrual, Accrual Anomaly, Idiosyncratic Risk and stock price. The values seen in the descriptive statistics are the maximum, minimum, average, and standard deviation values. The results of the descriptive statistical test in this study can be seen in the table below.

\section{Table 1}

\section{Descriptive Statistics}

Descriptive statistics

\begin{tabular}{ll|l|l|l|l} 
Variable & N & Minimum & Maximum & Mean & Std. Deviation \\
\hline Stock price & 457 & 1.396394611 & 5.471841892 & 3,4134952400 &, 798262616000 \\
\hline IdiosyncraticRisk & 457 & $-3,72573075$ &, 856604160 & -1.1268501230 &, 757497250000 \\
\hline CurrentOperatingAcc & 457 & 3.403534684 & 8.622597605 & 6,22805142500 &, 890578603000 \\
\hline NonCurrentOperatingAcc & 457 & 3,972781608 & 9,325747687 & 6.5179912040 &, 916559883000 \\
\hline
\end{tabular}

Source: Data of Sports (2017)

Multivariate testing in this study requires the fulfillment of the normality assumption. This test is performed when Amos's operation runs. There are two tests of normality, namely univariate normality, and multivariate normality. A data distribution can be considered normal if the value of $C R C R$ Skewness and kurtosis value is smaller than the critical value table $\hat{A} \pm 1.96$ with a 0.05 significance level ( $p$-value $5 \%$ ). The following table is the result of univariate and multivariate normality test with Amos program version 24.

Table 2

Result Testing normality

Assessment of normality (Group number 1)

\begin{tabular}{lllllll}
\hline Variable & Min & Max & Skew & & Cr & Kurtosis \\
\hline CurrentOperatingAcc & 3,404 & 8,623 &,- 004 &,- 037 &,- 019 &,- 082 \\
NonCurrentOperatingAcc & 3.973 & 9,326 &, 182 & 1.588 &,- 204 &,- 888 \\
IdiosyncraticRisk & $-3,726$ &, 857 &,- 386 & $-3,364$ &, 037 &, 159 \\
Stock price & 1,396 & 5,472 &, 175 & 1.524 &,- 223 &,- 971
\end{tabular}


Source: data preparation (2017)

Univariate analysis in Table 4.2 above, it is known that there is a variable that has a value of skewness and kurtosis $C R$ is greater than the critical value table \pm 1.96 . Thus it can be concluded that the univariate and multivariate data distribution is normal at the 0.05 significance level ( $p$-value $5 \%$ ). Multivariate testing is done, it is known that the $C R$ kurtosis of 0,282 is smaller than the critical value table $\hat{A} \pm 1.96$. It can be concluded in multivariate data distribution is normal.

Multikolinearitas testing aims to test whether the regression model found a strong correlation between the exogenous variables. The result of multicollinearity assumption test in this research can be seen in table below.

Table 3

Result of Multicollinearity Testing

Testing Substructure 1 Dependent Variable: Idiosyncratic Risk

\begin{tabular}{|c|c|c|c|c|c|c|c|c|}
\hline \multicolumn{2}{|c|}{ Model } & \multicolumn{2}{|c|}{$\begin{array}{l}\text { Unstandardized } \\
\text { Coefficients }\end{array}$} & \multirow{2}{*}{$\begin{array}{l}\text { Standardi } \\
\text { zed } \\
\text { Coefficie } \\
\text { nts } \\
\text { Beta }\end{array}$} & \multirow[t]{2}{*}{$T$} & \multirow[t]{2}{*}{ Sig } & \multicolumn{2}{|c|}{$\begin{array}{l}\text { Collinearity } \\
\text { Statistics }\end{array}$} \\
\hline & & B & $\begin{array}{l}\text { Std.Err } \\
\text { or }\end{array}$ & & & & $\begin{array}{l}\text { Toleran } \\
\text { ce }\end{array}$ & VIF \\
\hline \multirow[t]{3}{*}{1} & (Constant) &,- 468 &, 265 & & $-1,767$ & 078 & & \\
\hline & CurrentOperatingAcc &.,- 109 &, 029 &,- 128 & $-3,743$ & 000 &, 543 & 1.840 \\
\hline & $\begin{array}{l}\text { NonCurrentOperating } \\
\text { Acc }\end{array}$ &, 115 &, 029 &, 140 & 3,993 & 000 &, 521 & 1.919 \\
\hline
\end{tabular}

Source: Processed data (2017)

Table 4

Testing Substructure 2 Dependent Variable: The stock price

\begin{tabular}{|c|c|c|c|c|c|c|c|}
\hline \multirow[t]{2}{*}{ model } & \multicolumn{2}{|c|}{$\begin{array}{l}\text { Unstandardize } \\
\text { d Coefficients }\end{array}$} & \multirow{2}{*}{ 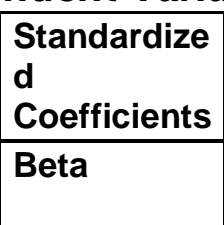 } & \multirow[t]{2}{*}{$T$} & \multirow[t]{2}{*}{ Sig. } & \multicolumn{2}{|c|}{$\begin{array}{l}\text { Collinearity } \\
\text { Statistics }\end{array}$} \\
\hline & B & $\begin{array}{l}\text { Std.Err } \\
\text { or }\end{array}$ & & & & $\begin{array}{l}\text { Tolera } \\
\text { nce }\end{array}$ & VIF \\
\hline \begin{tabular}{l|l}
2 & (Constant)
\end{tabular} & 2,158 &, 165 & & $\begin{array}{l}13,10 \\
9\end{array}$ &, 000 & & \\
\hline
\end{tabular}




\begin{tabular}{|l|l|l|l|l|l|l|l|}
\hline CurrentOperatingAcc &,- 002 &, 018 &,- 002 &,- 086 &, 932 &, 527 & $\begin{array}{l}1.89 \\
7\end{array}$ \\
\hline $\begin{array}{l}\text { NonCurrentOperatingA } \\
\text { cc }\end{array}$ &, 332 &, 018 &, 381 & $\begin{array}{l}18,22 \\
2\end{array}$ &, 000 &, 503 & $\begin{array}{l}1.98 \\
7\end{array}$ \\
\hline IdiosyncraticRisk &, 440 &, 029 & 417 & $\begin{array}{l}15,10 \\
6\end{array}$ &, 000 &, 288 & $\begin{array}{l}3,47 \\
3\end{array}$ \\
\hline
\end{tabular}

Source: Processed data (2017)

Based on table 4.3 above, it can be seen that all exogenous variables for both substructure equation 1 and substructure equation 2 have tolerance values $>$ 0.10 and $\mathrm{VIF}<10$, it can be concluded that there are no symptoms of multicollinearity.Thus, the assumption of multicollinearity in this study has been fulfilled.

\section{Conformity Testing Model (goodness of fit Model)}

The model fitness test (goodness of fit model) was conducted to test the suitability of the model submitted through various testing criteria.

Table 5

Model suitability Level Measurement (Goodness of Fit Model)

\begin{tabular}{llll}
\hline Measurement & Cut of value & $\begin{array}{l}\text { Value } \\
\text { Results }\end{array}$ & Acceptance Rate \\
\hline Chi-square & $\begin{array}{l}\text { Chi-square expected } \\
<9,488 \text { with DF }=4\end{array}$ & $\mathbf{6 , 0 7 8}$ & Good \\
P-value & 0.05 & $\mathbf{0 . 1 9 3}$ & Good \\
NFI & 0.05 & $\mathbf{0 . 9 9 7}$ & Good \\
CFI & 0.95 & .999 & Good \\
RMSEA & $<0.05$ & $\mathbf{0 . 0 3 4}$ & Good \\
Pratio & $0-1$ & $\mathbf{0 . 2 6 7}$ & Good \\
PNFI & $0-1$ & $\mathbf{0 . 2 6 6}$ & Good \\
PCFI & $0-1$ & $\mathbf{0 . 2 6 6}$ & Good \\
Hoelter & Â \%o $¥ 200$ & $\mathbf{7 1 2}$ & Good \\
\hline
\end{tabular}

Source: processed data (2017)

After testing the suitability of the model (Goodness of Fit Model), it can be tested against the hypothesis by using a regression model in path 
analysis (path analysis) to predict the relationship between exogenous and endogenous variables.

Based on the above path analysis, presented below are the path coefficients standardized structural equation this study.

Table 6

Coefficient of standardized Line Value

\begin{tabular}{|c|c|c|c|c|c|c|}
\hline \multicolumn{3}{|c|}{ The combination of variables } & \multicolumn{3}{|l|}{ Estimate } & $\mathrm{P}$ \\
\hline IdiosyncraticRisk & --- & NonCurrentOperatingAcc &, 115 & 029 & ,037 & $* \star *$ \\
\hline IdiosyncraticRisk & --- & CurrentOperatingAcc &,- 109 & 029 & 3.784 & $* * \star$ \\
\hline AssetPricing & --- & IdiosyncraticRisk &, 440 & 029 & 5.189 & *** \\
\hline AssetPricing & --- & CurrentOperatingAcc &,- 002 & 018 &, 087 & 931 \\
\hline AssetPricing & --- & NonCurrentOperatingAcc & , 332 & 018 & 8.438 & $* \star *$ \\
\hline
\end{tabular}

The magnitude of the path coefficients obtained shows the direct influence of standardized beta coefficient based on the t-statistic of each variable, while the magnitude of the indirect effect is obtained by multiplying the path coefficients indicate a direct effect of exogenous variables on mediating variables on endogenous variables. The magnitude of the effect is the sum total of the effect of direct and indirect influence.

\section{Table 7}

Calculation of direct influence can be seen in table 6 below exposure.

\begin{tabular}{lccc}
\hline \multicolumn{2}{c}{ The combination of variables } & Direct Impact \\
\hline IdiosyncraticRisk & & NonCurrentOperatingAcc &, 115 \\
IdiosyncraticRisk & -- & CurrentOperatingAcc &,- 109 \\
Stock price & --- & IdiosyncraticRisk &, 440 \\
AssetPricing & --- & CurrentOperatingAcc &,- 002 \\
AssetPricing & --- & AccrualAnomaly &, 303 \\
AssetPricing & --- & NonCurrentOperatingAcc &, 332 \\
\hline
\end{tabular}


Source: Data processing (2017)

Based on the above path analysis, presented below are the path coefficients standardized structural equation this study.

\section{Calculation of Indirect Influence}

The total effect on the calculation, the value of each variable summed, as can be seen in the table below:

Table 8

Effect of Indirect Variables

\begin{tabular}{llc}
\hline The combination of variables & Calculation & Results \\
\hline $\begin{array}{l}\text { Current Operatng Accrual -> The stock price via } \\
\text { Idiosyncratic Risk }\end{array}$ & $(-0.109) \times(0.440)$ & -0.04796 \\
$\begin{array}{l}\text { Accrual Non-Current Operatng -> The stock price via } \\
\text { Idiosyncratic Risk }\end{array}$ & $(0.115) \times(0.440)$ & 0.005060 \\
\end{tabular}

The total effect on the calculation, the value of each variable summed, as can be seen in table below

Table 9

Effect of Total Variables

\begin{tabular}{lcc}
\hline The combination of variables & Calculation & Results \\
\hline $\begin{array}{l}\text { Current Operatng Accrual -> The stock price via } \\
\text { ldiosyncratic Risk }\end{array}$ & $(-0.002)+(-0.04796)$ & 0.04996 \\
$\begin{array}{l}\text { Accrual Non-Current Operatng -> The stock price via } \\
\text { ldiosyncratic Risk }\end{array}$ & $(0.332)+(0.005060)$ & 0.33706 \\
\hline
\end{tabular}

\section{Calculation of Value significance Effect of Mediation (Sobel Test)}

The significant value of the role of variable intermediation is obtained by calculating the estimated value (estimate) and standard error (SE) of a track ( $\mathrm{Ng}$ et. Al., 2015) (Sobel, 1982) with the following formula: $z$-value $=a{ }^{*} b /$ SQRT $\left(b^{2 *} \operatorname{Se}_{a}{ }^{2}+a^{2 *} \mathrm{SE}_{b}{ }^{2}\right)$ 
Table 10

Calculation Results in significance Value Testing Not directly (Sobel Test)

\begin{tabular}{|c|c|c|c|c|c|}
\hline $\begin{array}{l}\text { variable } \\
\text { combination }\end{array}$ & $\begin{array}{l}\text { the } \\
\text { estim } \\
\text { ated } \\
\text { value }\end{array}$ & $\begin{array}{l}\text { Stan } \\
\text { dard } \\
\text { Erro } \\
r\end{array}$ & $\begin{array}{l}\text { Sobel test } \\
\text { statistic }\end{array}$ & $\begin{array}{l}\text { One-tailed } \\
\text { probability }\end{array}$ & $\begin{array}{l}\text { Two-tailed } \\
\text { probability }\end{array}$ \\
\hline $\begin{array}{l}\text { Current Operatng } \\
\text { Accrual -> stock } \\
\text { price via } \\
\text { Idiosyncratic Risk }\end{array}$ & $\begin{array}{l}-0.109 \\
0.440\end{array}$ & $\begin{array}{l}0,029 \\
0,029\end{array}$ & -3.64834031 & 0.00013197 & 0.00026394 \\
\hline $\begin{array}{l}\text { Accrual Non-Current } \\
\text { Operatng -> The } \\
\text { stock price via } \\
\text { Idiosyncratic }\end{array}$ & $\begin{array}{l}0,115 ; .4 \\
40\end{array}$ & $\begin{array}{l}0,029 \\
0,029\end{array}$ & 3.83663958 & 0.00006236 & 0.00012473 \\
\hline
\end{tabular}

Source: Calculations with the aid of statistics programs calculators BETA Version 3 (2015), HTTP; // www.danielsoper.com/statcalc3/calc. aspx?id=31 Based on the calculation results in Table 4.9 Sobel test can be explained as follows:

1. The indirect effect of the Accrual Operating Current stock price has a pvalue (two-tailed probability) Sobel test of 0.00026394 <alpha 0.05

2. The indirect effect of Non-Current Operating Accrual to the stock price had p-value (two-tailed probability) Sobel test of 0.00012473 $<$ alpha 0.05

Results of testing the hypothesis in this study are summarized in the following table.

Table 11

Testing Results Hypothesis

\begin{tabular}{|c|c|c|}
\hline Variable & P-value & $\begin{array}{l}\text { Hypothesis } \\
\text { testing } \\
\text { results }\end{array}$ \\
\hline H1. Operating Current accrual $\square \square$ Idiosyncratic Risk & *** & accepted \\
\hline H2. Operating Current accrual $\square \square$ stock price & , 931 & rejected \\
\hline $\begin{array}{l}\text { H3. Operating Current accrual } \square \text { stock price via } \\
\text { Idiosyncratic Risk }\end{array}$ & 0.04996 & accepted \\
\hline $\begin{array}{l}\text { Operating Current H4.Non- accrual } \square \square \text { ldiosyncratic } \\
\text { Risk }\end{array}$ & *** & accepted \\
\hline
\end{tabular}




\begin{tabular}{llc}
\hline Operating Current H5.Non- accrual $\square \square$ stock price & $* * *$ & accepted \\
$\begin{array}{l}\text { H6. Non-accrual Current Operating } \square \square \text { stock price via } \\
\text { Idiosyncratic Risk }\end{array}$ & 0.00012473 & accepted \\
Idiosyncratic Risk H7 $\square \square$ stock price & $* * *$ & be accepted \\
\hline
\end{tabular}

Data processing (2017)

\section{DISCUSSION AND RESEARCH FINDINGS}

Results show that the persistence of current operating accrual has a negative and significant impact on the idiosyncratic risk. The results of this study are not consistent with research Lin and Wang (2011) found that the value relevance of financial statements will improve the idiosyncratic risk. These results are consistent with studies that examine the relationship of the quality of financial statements with information such as the study of risk Easley and O'Hara (2004); Francis et al. (2005); Lambert et al., (2007); Gray et al., (2009). The study is based on theoretical models suggested that the risk information is a risk factor that can not be diversified.

Accruals quality as a measure of risk associated with financial statement information, using the accrual quality can be seen how much the accuracy of working capital accruals into the realization of operating cash flow in order to see the quality of the current operating company reported. The behavior of investors to the proportion of private information and public information. The asymmetry of information that occurs when high levels of private information will increase the risks faced by the less informed investors. This risk is a risk that can not be diversified and will encourage less informed investors to ask for return larger so that cost of capital increases. If the company wants to lower the cost of capital, can be done to mitigate risks faced by information less informed investors.

These result in terms of real options is a right given to the manager to take the best action of the alternative changes in accounts receivable, inventories and current liabilities. The decision is conditional is an inherent part in a real option. Real options used in connection persistence of accruals and Idiosyncratic risk to understand the behavior of the company's investment in industry dynamics and government policies. The content of the information accrual against idiosyncratic risk. Idiosyncratic risk is influenced by 
monetary policy, characteristic factors of the company, funding policy and the company's operating activities of companies that short-term accruals affect the risk.

The accounting treatment and disclosure could affect the company's information environment and the impact on information risk, volatility and idiosyncratic, and cost of capital, so that the relationship of financial information and Idiosyncratic risk is based on the dimensions of this company quality operation accruals as a measure of risk information. Research operation in this dimension is measured using a persistence operating current accrual which measures the change in current assets accounts receivable, inventory and change of current debts. Changes in accounts receivable and inventories and liabilities are the options granted to management. Management decisions related to changes in accounts receivable, inventories and current liabilities is inherent in this part of the theory of real options.

\section{E. Conclusion}

This study aimed to examine the effect of persistence accrual operating current, operating noncurrent accrual persistence, idiosyncratic risk stock prices. By using a sample of 94 companies listed in Indonesia Stock Exchange 20102015 period resulted in some conclusions as follows.

1. persistence of current operating accrual has a negative and significant impact on the idiosyncratic risk. The results of this study correlate negatively indicates that investors view the current operating persistence accrual as changes in current assets and current liabilities are not unidirectional company-specific risk premises. The increase in operating current accrual changes being considered a specific risk reduction company. This is because the Indonesian capital market investors more trading within a short time.

2. persistence of current operating accrual has no influence stock prices. Indonesian capital market investors do not consider the change in operating current accrual as forming part of the stock price.

3. Current operating accruals have an influence on the stock price through the idiosyncratic risk is accepted. Presentation of the statement of changes in current assets and current liabilities of the issuer company is 
seen by investors and capital market analysts as the company's specific risk to the impact on stock prices. This condition is caused due to the company's operational needs and the needs of the dividend payment are considered important by investors.

4. Persistence non-current operating accruals have a positive and significant impact on the idiosyncratic risk. Investors looking at the change in operating non-current accrual as a change on account of fixed assets is a specific risk to the company. The increase in this account tells us the increase in risk.

5. Persistence non-current operating accruals have a positive and significant impact on stock prices. It tells us the change of operating current accounts accrual seen by investors is very important with regard to the continued operation of a manufacturing company that deals with stock prices.

6. Persistence Current non-operating accrual has an influence on the stock price through the idiosyncratic risk is acceptable. The presentation of changes in assets and liabilities of the company's long-term issuer is seen by investors and capital market analysts as the company's specific risk to the impact on stock prices. This condition is caused due to the operational needs of the company with regard to the use of fixed assets in the machinery and equipment manufacturing companies considered important by investors

7. Idiosyncratic Risk has a positive and significant impact on stock prices 


\section{F. References}

Aiyagari, S. R. (1994). Uninsured Idiosyncratic Risk and Aggregate Saving. Journal of Economics, 109(3), 659-684.

Ali, A., \& Paul Zarowin. (1992). The Role of Earnings Levels in Annual Earning Returns studies. Journal of Accounting Research, 30 no.2, 286-296.

Allen, E. J., Larson, C. R., \& Sloan, R. G. (2010). Accrual Reversals, Earnings and Stock Returns, (May).

Ang, A., Hodrick, R. J., Xing, Y., \& Zhang, X. (2006). The Cross-Section of Volatility and Expected Return. Journal of Finance, LXI(1), 259-299.

Ang, A., Hodrick, R. J., Xing, Y., \& Zhang, X. (2009). High idiosyncratic volatility and low returns: International and further U.S. evidence. Journal of Financial Economics, 91(1), 1-23. doi:10.1016/j.jfineco.2007.12.005

Angeletos, G. M. (2007). Uninsured idiosyncratic investment risk and aggregate saving. Review of Economic Dynamics, 10(1), 1-30. doi:10.1016/j.red.2006.11.001

Arena, M. P., Haggard, K. S., \& Yan, X. S. (2008). Price Momentum and Idiosyncratic Volatility. Financial Review, 43(2), 159-190. doi:10.1111/j.15406288.2008.00190.x

Artikis, P. G., \& Papanastasopoulos, G. a. (2016). Implications of the cash component of earnings for earnings persistence and stock returns. The British Accounting Review. Elsevier Ltd. doi:10.1016/j.bar.2016.02.002

Asri, M., Ali, M., Habbe, A. H., \& Rura, Y. (2017). Idiosyncratic Risk as Indicator Asset Pricing. Scientific Research Journal (SCIRJ) http://www.scirj.org/2017/may-2017-paper.php?rp=P0517398, V(V), 5-18.

Bali, T. g, Cakici, N., Yan, X., \& Zhang, Z. (2005). Does Idiosyncratic Risk Really Matter? The Journal of Finance, 60(2), 905-929. doi:10.1111/j.15406261.2005.00750.x

Basilico, E. (2014). The Quality of Earnings, Governance and Future Stock Returns in Europe. An Empirical Study . Disertation University St.Gallen, (4203).

Basu, S. (1997). The conservatism principle and the asymmetric timeliness of earnings: An event-based approach. Journal of Accounting and Economics, 30(1), 215-241. doi:10.1111/j.1911-3846.2011.01151.x

Berggrun, L., Lizarzaburu, E., \& Cardona, E. (2016). Idiosyncratic volatility and stock returns: Evidence from the MILA. Research in International Business and Finance, 37, 422-434. doi:10.1016/j.ribaf.2016.01.011

Bernard, V. L. ( U. of M. B. S., \& Skinner, D. J. (University O. M. B. S. (1996). What motivates managers' choice of discretionary accruals? Journal of Accounting and Economics, 22(1-3), 313-325. doi:10.1016/S0165-4101(96)00431-4

Berrada, T., \& Hugonnier, J. (2013). Incomplete information, idiosyncratic volatility, and stock returns. Journal of Banking and Finance, 37(2), 448-462. doi:10.1016/j.jbankfin.2012.09.004

Bhootra, A., \& Hur, J. (2014). High Idiosyncratic Volatility and Low Returns: A Prospect Theory Explanation. Financial Management, 1-26. 
Black, F. (1986). Noise. The Journal of Finance, 41(3), 529-543. doi:10.1111/j.15406261.1986.tb04513.x

Bolton, P., Chen, H., \& Wang, N. (2011). A Unified Theory of Tobin's q, Corporate Investment, Financing, and Risk Management. Journal of Finance, 66(5), 15451578. doi:10.1111/j.1540-6261.2011.01681.x

Bradshaw, M. T., Richardson, S. a., \& Sloan, R. G. (2006). The relation between corporate financing activities, analysts' forecasts, and stock returns. Journal of Accounting and Economics, 42(1-2), 53-85. doi:10.1016/j.jacceco.2006.03.004

Brockman, P., Schutte, M. G., \& Yu, W. (2009). Is Idiosyncratic Risk Priced? The International Evidence. Working Paper, University of Missouri-Columbia, (906), $1-52$.

Chen, C. (2004). Earnings persistence and stock price under-and overreaction. Working Paper, (March). Retrieved from http://www.saf.uwaterloo.ca/seminars/old_papers/Changling Chen_Earnings Persistence and Stock Prices.pdf

Chen, H., \& Chen, S. (2012). Investment-cash flow sensitivity cannot be a good measure of financial constraints: Evidence from the time series. Journal of Financial Economics, 103(2), 393-410. doi:10.1016/j.jineco.2011.08.009

Cogley, T. (2002). Idiosyncratic risk and the equity premium: Evidence from the consumer expenditure survey. Journal of Monetary Economics, 49(2), 309-334. doi:10.1016/S0304-3932(01)00106-4

Collins, D. W., \& Hribar, P. (2000). Earnings-based and accrual-based market anomalies: one effect or two? Journal of Accounting and Economics, 29(1), 101123. doi:10.1016/S0165-4101(00)00015-X

Cotter, J., Sullivan, N. O., \& Rossi, F. (2015). The conditional pricing of systematic and idiosyncratic risk in the UK equity market. International Review of Financial Analysis, 37, 184-193. doi:10.1016/j.irfa.2014.10.002

Dechow, P., Ge, W., \& Schrand, C. (2010). Understanding earnings quality: A review of the proxies, their determinants and their consequences. Journal of Accounting and Economics, 50(2-3), 344-401. doi:10.1016/j.jacceco.2010.09.001

Dechow, P. M. (1994). Accounting \& Economics The role of accounting accruals. Journal of Accounting and Economics, 18, 3-42. doi:10.1016/01654101(94)90016-7

Dechow, P. M., Richardson, S. a., \& Sloan, R. G. (2008). The persistence and pricing of the cash component of earnings. Journal of Accounting Research, 46(3), 537566. doi:10.1111/j.1475-679X.2008.00283.x

Dechow, P., Sloan, R. G., \& Sweeney, A. (1995). Detecting Earning Management. The Accounting Review, 70 No.2, 193-225.

Dixit, A., \& Pindyck, R. (1994). Investment Under Uncertainty. Princenton U.press, 140.

Durnev, A., Li, T., \& Magnan, M. (2016). Are offshore fi rms worth more? Journal of Corporate Finance, 36, 131-156. doi:10.1016/j.jcorpfin.2015.11.002

Durnev, A., Morck, R., Yeung, B., \& Zarowin, P. (2003). Does Greater Firm-Specific Return Variation Mean More or Less Informed Stock Pricing? Journal of Accounting Research, 41(5). 
Easley, D., \& O'Hara, M. (2004). Information and the Cost of Capital. The Journal of Finance, $L I X(4)$.

Fairfield, P. M. (2006). Discussion of "The persistence of earnings and cash flows and the role of special items: Implications for the accrual anomaly." Review of Accounting Studies, 11(2-3), 297-303. doi:10.1007/s11142-006-9005-0

Fairfield, P. M., Whisenant, J. S., \& Yohn, T. L. (2003). Accrued Earnings and Growth: Implications for Future Profitability and Market Mispricing. The Accounting Review, 78(1), 353-371.

Fama, E. F. (1965). The Behavior of Stock Market Price. Journal of Business, 38(!), 31-105.

Fama, E. F., \& French, K. R. (1993). Common risk factors in the returns on stocks and bonds. Journal of Financial Economics.

Fama, E. F., \& French, K. R. (1996). Multifactor Explanations of Asset Pricing Anomalies. The Journal of Finance, L/(1), 55-84. doi:10.2307/2329302

Fama, E. F., \& French, K. R. (2006). Profitability, investment and average returns. Journal of Financial Economics, 82(3), 491-518. doi:10.1016/j.jfineco.2005.09.009

Fama, E. F., \& French, K. R. (2014). A five-factor asset pricing model. Journal of Financial Economics, 116(1), 1-22. doi:10.1016/j.jfineco.2014.10.010

Fan, S., \& Yu, L. (2013). Accrual Anomaly and Idiosyncratic Risk: International Evidence. The International Journal of Business and Finance Research, 7(4), 63-75.

Retrieved

from http://search.proquest.com/docview/1352855709?accountid=48385

Francis, J., Lafond, R., \& Schipper, K. (2004). Costs of Equity and Earnings Attributes. The Accounting Review, 79(4), 967-1010.

Francis, J., Smith, M., Francis, J., \& Smitht, M. (2005). A Reexamination of the Persistence of Accruals and Cash Flows. Journal of Accounting Research, 43(3), 413-451. doi:10.1111/j.1475-679X.2005.00176.x

Frankel, R., \& Litov, L. (2009). Earnings persistence. Journal of Accounting \& Economics, 47, 182-190. doi:10.1016/j.jacceco.2008.09.005

$\mathrm{Fu}, \mathrm{F}$. (2009). Idiosyncratic risk and the cross-section of expected stock returns. Journal of Financial Economics, 91(1), 24-37. doi:10.1016/j.jfineco.2008.02.003

Goyal, A., \& Santa-clara, P. (2003). Idiosyncratic Risk Matters! Journal of Finance, 58(3), 975-1007.

Gray, P., Koh, P., \& Tong, Y. H. (2009). Accruals Quality, Information Risk and Cost of Capital: Evidence from Australia. Journal of Business Finance \& Accounting, 36(March), 51-72. doi:10.1111/j.1468-5957.2008.02118.x

Harvey, C. R. (1995). Predictable Risk and returns in Emerging Markets. Oxford Journal.

Healy, P. M., \& Palepu, K. G. (1990). EFFECTIVENESS OF ACCOUNTING-BASED DMDEND COVENANTS* Paul M. HEALY. Journal of Accounting and Economics, 12, 97-123.

Healy, P. M., \& Palepu, K. G. (1995). The challenges of investor communication The case of CUC International, Inc. Journal of Financial Economics, 38(2), 111-140. doi:10.1016/0304-405X(94)00814-H 
Herskovic, B., Kelly, B., Lustig, H., \& Nieuwerburgh, S. Van. (2015). The common factor in idiosyncratic volatility: Quantitative asset pricing implications. Journal of Financial Economics, 1-53. doi:10.1016/j.jfineco.2015.09.010

Hirshleifer, D., Hou, K., \& Teoh, S. H. (2012). The Accrual Anomaly: Risk or Mispricing? Management Science, 58(2), 320-335. doi:10.1287/mnsc. 1100.1289

Hirshleifer, D., \& Teoh, S. H. (2009). The Psychological Attraction Approach to Accounting and Disclosure Policy David. Mpra, University of California Irnine, (14046).

Huang, B., Wald, J., \& Martell, R. (2013). Financial market liberalization and the pricing of idiosyncratic risk. Emerging Markets Review, 17, 44-59. doi:10.1016/j.ememar.2013.08.005

Huang, W., Liu, Q., Ghon Rhee, S., \& Zhang, L. (2011). Another Look at Idiosyncratic Volatility and Expected Returns. Journal of Investment Management, 9(4), 26. Retrieved from file://localhost/Users/christian/Documents/Papers/2011/Journal of Investment Management/Huang2011Another Look at Idiosyncratic Volatility_Journal of Investment Management94_26.pdf

Hui, K. W., Nelson, K. K., \& Yeung, P. E. (2015). On the persistence and pricing of industry-wide and firm-specific earnings, cash flows, and accruals. Journal of Accounting and Economics, 1-18. doi:10.1016/j.jacceco.2015.06.003

Jiang, G. J., Xu, D., \& Yao, T. (2009). The Information Content of Idiosyncratic Volatility. Journal of Financial and Quantitative Analysis, 44(01), 1-28. doi:10.1017/S0022109009090073

Jiang, W., Lee, P., \& Anandarajan, A. (2008). The association between corporate governance and earnings quality: Further evidence using the GOV-Score. Advances in Accounting, 24(2), 191-201. doi:10.1016/j.adiac.2008.08.011

Jin, L., \& Myers, S. C. (2006). R 2 around the world: New theory and new tests, 79, 257-292. doi:10.1016/j.jfineco.2004.11.003

Jones, J. J. (1991). Earnings Management During Import Relief Investigations. Journal of Accounting Research, 29(2), 193-228. doi:10.2307/2491047

Kahneman, D., \& Tversky, A. (1979a). Prospect Theory: An Analysis of Decision under Risk. Econometrica: Journal of the Econometric Society, 47(March), 263291. doi:10.1111/j.1536-7150.2011.00774.x

Kahneman, D., \& Tversky, A. (1979b). Prospect Theory: An Analysis of Decision Under Risk. Econometrica, 47 No.2(9), 1689-1699. doi:10.1017/CBO9781107415324.004

Ke, B., \& Ramalingegowda, S. (2005). Do institutional investors exploit the postearnings announcement drift ? Journal of Accounting \& Economics, 39, 25-53. doi:10.1016/j.jacceco.2004.02.002

Khovansky, S., \& Zhylyevskyy, O. (2013). Impact of idiosyncratic volatility on stock returns: A cross-sectional study. Journal of Banking and Finance, 37(8), 30643075. doi:10.1016/j.jbankfin.2013.02.034

Kim, Y. J., Kim, J. H., Kwon, S., \& Lee, S. J. (2015). Percent accruals and the accrual anomaly: Korean evidence. Pacific Basin Finance Journal, 35, 340-366. doi:10.1016/j.pacfin.2015.02.006 
Kumari, J., Mahakud, J., \& Hiremath, G. S. (2017). stock market. Research in International Business and Finance, 41(April), 172-184. doi:10.1016/j.ribaf.2017.04.022

Lambert, R. A., Leuz, C., \& Verrecchia, E. (2011). Information Asymmetry, Information Precision, and the Cost of Capital. Review of Finance, 1-29. doi:10.1093/rof/rfr014

Lee, B. S., \& Mauck, N. (2016). Dividend initiations, increases and idiosyncratic volatility. Journal of Corporate Finance, 40, 47-60. doi:10.1016/j.jcorpfin.2016.07.005

Lev, B., \& Nissim, D. (2006). The persistence of the accruals anomaly. Contemporary Accounting Research, 23(1), 193-226. doi:10.1506/c6wa-y05n-0038-cxtb

Lin, Y., \& Wang, T. S. (2011). Value Relevance, Idiosyncratic Risk, and External Financing Activities Value Relevance, Idiosyncratic Risk, and External Financing Activities. SSRN Electronic Journal.

Lintner, J. (1965). the Valuation of Risk Assets and the Selection of Risky Investments in Stock Portfolios and Capital Budgets. The Review of Economics and Statistics, 47(1), 13-37.

Liow, K. H., \& Addae-Dapaah, K. (2010). Idiosyncratic risk, market risk and correlation dynamics in the US real estate investment trusts. Journal of Housing Economics, 19(3), 205-218. doi:10.1016/j.jhe.2010.06.001

Malagon, J., Moreno, D., \& Rodríguez, R. (2015). Time horizon trading and the idiosyncratic risk puzzle. Quantitative Finance, 15(2), 327-343. doi:10.1080/14697688.2012.755560

Malkiel, B. G., \& Xu, Y. (2006). Idiosyncratic Risk and Security Returns. Department of Economics Pirncenton University, (972), 1-57. doi:10.2139

Mashruwala, C., Rajgopal, S., \& Shevlin, T. (2006). Why is the accrual anomaly not arbitraged away? The role of idiosyncratic risk and transaction costs. Journal of Accounting and Economics, 42(1-2), 3-33. doi:10.1016/j.jacceco.2006.04.004

Mendenhall, R. R. (2014). Arbitrage Risk and Post- Earnings-Announcement Drift *. The Journal of Business, 77(4), 875-894.

Merton, R. C. (1986). A Simple Model of Capital Market Equilibrium with Incomplete Information. Journal of Finance, 42(3), 483-510.

Merton, R. C. (1987). A Simple Model of Capital Market Equilibrium with Incomplete Information. Journal of Finance, 42(3), 483-510. doi:10.1111/j.15406261.1987.tb04565.x

Miller, M. H., \& Rock, K. (1985a). Dividend Policy under Asymmetric Information. The Journal of Finance, XL(4), 1031-1051.

Miller, M. H., \& Rock, K. (1985b). Dividend Policy under Asymmetric Information. The Journal of Finance, 40(4), 1031-1051.

Morck, R., Yeung, B., \& Yu, W. (2000). The information content of stock markets: why do emerging markets have synchronous stock price movements? Journal of Financial Economics, 58(1-2), 215-260. doi:10.1016/S0304-405X(00)00071-4

Myers, S. C. (1977). DETERMINANTS OF CORPORATE BORROWING. Journal of Financial Economics, 5, 147-175. 
Myers, S. C. (1984). The Capital Structure Puzzle. The Journal of Finance, 39(3), 575-592.

Nartea, G. V., Ward, B. D., \& Yao, L. J. (2011). Idiosyncratic volatility and crosssectional stock returns in Southeast Asian stock markets. Accounting and Finance, 51(4), 1031-1054. doi:10.1111/j.1467-629X.2010.00384.x

Nartea, G. V., Wu, J., \& Liu, Z. (2013). Does idiosyncratic volatility matter in emerging markets? Evidence from China. Journal of International Financial Markets, Institutions and Money, 27(1), 137-160. doi:10.1016/j.intfin.2013.09.002

Nath, H. B., \& Brooks, R. D. (2015). Assessing the idiosyncratic risk and stock returns relation in heteroskedasticity corrected predictive models using quantile regression. International Review of Economics and Finance, 38, 94-111. doi:10.1016/j.iref.2014.12.012

Ng, S., Pahlevi, C., Harryanto, \& Habbe, A. H. (2015). Managerial Ability and Monitoring Structure as a Mechanism for Improving the Quality of Earnings and the Value of the Firms Listed In Indonesia Stock Exchange. Scientific Research Journal (SCIRJ), III(Xi), 25-39.

Pincus, M., Rajgopal, S., \& Venkatachalam, M. (2007). The accrual anomaly: International evidence. Accounting Review, 82(1), 169-203. doi:10.2308/accr.2007.82.1.169

Prono, T. (2015). Market proxies as factors in linear asset pricing models: Still living with the roll critique. Journal of Empirical Finance, 31, 36-53. doi:10.1016/j.jempfin.2015.02.001

Resutek, R. J. (2010). Intangible Returns, Accruals, and Return Reversal: A Multiperiod Examination of the Accrual Anomaly. The Accounting Review, 85(4), 1347-1374. doi:10.2308/accr.2010.85.4.1347

Richardson, S. a., Sloan, R. G., Soliman, M. T., \& Tuna, I. (2005). Accrual reliability, earnings persistence and stock prices. Journal of Accounting and Economics, 39(3), 437-485. doi:10.1016/j.jacceco.2005.04.005

Roll, R. (1977). A Critique of The asset pricing Theorys Tests.Part1:on past and potential Testability of the theory. Journal of Financial Economics, 4, 129-176.

Roll, R., Schwartz, E., \& Subrahmanyam, A. (2014). Trading activity in the equity market and its contingent claims: An empirical investigation. Journal of Empirical Finance, 28, 13-35. doi:10.1016/j.jempfin.2014.05.007

Roll, R., \& Subrahmanyam, A. (2010). Liquidity skewness. Journal of Banking and Finance, 34(10), 2562-2571. doi:10.1016/j.jbankfin.2010.04.012

Rura, Y., Bambang, S., Made, S., \& Rosidi. (2011). Pengungkapan proforma dan Keputusan Investor: Uji Empiris Teori Signaling dan Teori Pasar Efisien di Bursa Efek Indonesia (BEI). Jurnal Akuntansi Multiparadigma, volume 2 N, 261-278.

Schrand, C. M., \& Zechman, S. L. C. (2012). Executive overconfidence and the slippery slope to financial misreporting. Journal of Accounting and Economics, 53(1-2), 311-329. doi:10.1016/j.jacceco.2011.09.001

Shanken, J., \& Zhou, G. (2007). Estimating and testing beta pricing models: Alternative method and their performance in simulations. Journal of Financial Economics. 
Sharpe, W. F. (1964). Capital Asset Prices: A Theory of Market Equilibrium under Conditions of Risk. The Journal of Finance, 19 no.3, 425-442.

Sloan, R. G. (1996). Do Stock Prices Fully Reflect Information in Accruals and Cash Flow about Futures Eranings?

Sobel, E. (1982). asymptotic confidence intervals for indirect effects in structural equation models. Sociological Methodology, 13(1982), 290-312.

Subramanyam, K. R. (1996). The pricing of discretionary accruals. Journal of Accounting and Economics, 22, 249-281. doi:10.1016/S0165-4101(96)00434-X

Xie, H. (2001). The Mispricing Accruals of Abnormal. The Accounting Review, 76(3), 357-373. doi:10.2308/accr.2001.76.3.357

Zhang, G. (2005). What Causes the Accrual Anomaly - Growth or Earnings Persistence? Working Paper, (November 2015), 0.

Zhu, P., Jog, V., \& Otchere, I. (2014). Idiosyncratic volatility and mergers and acquisitions in emerging markets. Emerging Markets Review, 19, 18-48. doi:10.1016/j.ememar.2014.04.001 